\title{
Students' Perception of Their Self-Efficacy as a Mechanism to Sustained Positive Attitude in Practical Agriculture
}

\author{
Jifin D. Tsojon \\ Graham A. Ehiemere \\ Fidelis H. Bonjoru \\ Agricultural Education Department, \\ College of Education, Zing, Taraba State, Nigeria
}

\section{Doi:10.5901/ ajis.2013.v2n10p137}

\begin{abstract}
This research examines the interest and self-efficacy of students of Colleges of Agriculture and Education both in Jalingo, Taraba state of Nigeria. A sample size of 186 agricultural students was drawn from the two institutions. The sample was drawn using proportionate stratified random sampling technique from agricultural students who had offered practical agriculture in their previous levels of study. The instrument used to elicit data for the study was a questionnaire termed students' interest and self-efficacy questionnaire (SISEQ). A reliability coefficient of the instrument, Cronbach alpha, of 0.91 was obtained. Descriptive statistics of mean and standard deviation were obtained and used. The result of the study revealed that students of agriculture showed strong positive interest in agricultural practical. Furthermore, the result added that students of agriculture were efficacious to agricultural practical. The study recommends that agricultural teachers should develop students' awareness of their self-efficacy to enable them exclaim "l can do it".
\end{abstract}

Keywords: Self-efficacy, Students' attitude, Practical agriculture, Interest, Anxiety.

\section{Introduction}

Preparing students for challenging careers in the crop production, animal production, irrigation, agricultural engineering, etc and technical skills are critical to adequately prepare agricultural students to be effective employees for the work force in a knowledge economy (Zarafshani, Knobloch \& Aghahi, 2008). The need for information, knowledge and skills needed by agricultural students, in Nigerian Colleges, to be effective in career and life planning decision cannot be over emphasized. Agriculture students need to have wide range of information to succeed in their career goals as well as feeling capable enough to manage and cope with everyday tasks.

For agriculture students to be successful in preparing themselves for challenging professional careers in agriculture, they need to have a high sense of self-efficacy. Self-efficacy is "the belief in ones' capabilities to organize and execute the courses of action required to manage prospective situations" (Bandura, 1994). It is the person's belief in his or her ability to succeed in a particular situation (Roberts \& Dyer, 2005; Wolf, 2008; Kurbanoglu \& Akim, 2010; Edziwa \& Chivheya, 2012; Hashemi, Hosseini \& Rezvanfar, 2012; \& Tenaw 2013). Other researchers refer to self-efficacy belief as the judgments about one's ability to organize and execute the courses of action required to produce given outcome (Zimmerman \& Cleary, 2006; Niemivirta \& Tapola, 2007; Zarafshani, Knobloch \& Aghahi 2008; du Preez, 2010). Self-efficacy is an "I can do it" belief that reflects one's accurate self assessment in his or her ability to effectively adapt and perform necessary tasks in 
the face of challenging environment. It is an important motivation for people to be successful in their careers. Self-efficacy plays a role in a student's academic motivation in terms of choice of activity, amount of effort expended on the academic task and the persistence shown in completing academic task. On a general view, self-efficacy can enhance human accomplishments and influence the choices people make and the courses of action they pursue, how long they will endure when confronting obstacles and how resilient they will be on the face of adverse situation. In the structure of conceptual model, perceived academic self-efficacy would contribute to a sense of personal efficacy for careers in scientific-technical, educational, medical, artistic-literary and commercial-managerial careers because they all call for advance knowledge and high level cognitive skills. A strong sense of academic efficacy would enhance perceived efficacy for the latter types of careers both directly and through the mediation of academic aspirations and scholastic achievements. That is it influences learning and performance (Bandura 1986, 1997, Niemivirta \& Tapola 2007; du Preez, 2010; Bandura, Barbaranelli, Caprara \& Pastorelli, 2001 and Ajegbomogun, 2011). Some researchers have also revealed that self-efficacy affect students' achievement and attitudes (Roberts \& Dyer, 2005).

Self-efficacy and self-concept beliefs at a glance seem to have minimal distinction between them. The two constructs represent different phenomena (Bandura, 1986). Self concept refers to a generalized self-assessment incorporating a variety of self-reactions and beliefs such as feelings of self-worth and general beliefs of competence. In contrast, self-efficacy beliefs are context-specific judgments of personal capability to organize and execute a course of action to attain a set goal. Self-efficacy focuses more specifically on the tasks or activities that an individual feels capable of performing rather than a more global assessment of "how good you are at something" as provided in assessment of self-concept (Zimmerman \& Cleary, $2006 \&$ Wolf, 2008). Self-esteem is another construct that is a type of belief involving judgments of self-worth. It is an affective reaction indicating how a person feels about him or herself. This is quite distinct from self-efficacy perceptions, which involves cognitive judgments on a personal capacity and capability (Pintrich \& Schunk, 2002).

Perceived self-efficacy is people's judgments of their capabilities to organize and execute courses of action required to attain designated types of performances. It is concerned not with the skills one has but with judgments of what one can do with whatever skills one possesses (Wolf, $2008 \&$ Hartfield, 2011). Self-efficacy beliefs are one of the strongest, if not the strongest, predictor of human motivation and behaviour. A strong sense of self-efficacy enhances accomplishment and personal well-being in part because of an individual's beliefs in their own potentials to influence the outcome. Individuals with a high sense of self-efficacy often exhibit an intrinsic interest and tend to be deeply engrossed in their activities; they set challenging goals and maintained a strong commitment to achieving these goals. Individuals with high sense of self-efficacy approach threatening situations with greater confidence, feeling they have at least some ability to exert an influence and/or a degree of control over the situation. That is, they recover quickly from setbacks and disappointments. Individuals with low self-efficacy tend to doubt their ability or potential to influence an outcome, generally avoid difficult or threatening situations, dwell on personal deficiencies when faced with difficult tasks, slacken efforts and give up in the face of adversity and are slow to recover from failure (Bandura, 1994).

Efficacy beliefs involve different types of capabilities, such as management of thought, affect, action and motivation. Beliefs related to self-efficacy allow individuals with a similar set of skills or attribute to perform the same function differently. Nonetheless, efficacy beliefs can only show true excelled performance if a skill set is available (Hartfield, 2011). Self-efficacy beliefs affect how people approach new challenges and will contribute to performance since these beliefs influence thought processes, motivation and behaviour. Self-efficacy is not static and can change over time resulting from periodic reassessments of how adequate one's performance has been (Bandura, 1986). Self-efficacy provides a mechanism to explain individual behaviour and is associated with a positive self-concept and self-appraisal of personal control which arises from experiences of 
mastery and the anticipation of competent performance. A person with a positive (high) selfefficacy expects to succeed and will persevere in his commitment to accomplish the task at hand. On the other hand, an individual with negative (low) self-efficacy anticipates failing and is not likely to persevere in the challenging task.

Individual self-efficacy is derived from four main sources namely (i) mastery experiences, (ii) vicarious experiences (iii) social persuasion and (iv) physiological and emotional (affective) states (Bandura 1977 \& 1982; Zimmerman \& Cleary, 2006; Wolf, 2008; \& Hartfield, 2011). Mastery experience is the most effective way to master a strong sense of self-efficacy. An individual's (student's) successful experiences boost self-efficacy, while failures erode it. Successes build a robust belief in one's efficacy. After individuals are convinced they have the ability to succeed at a task, they are much more resilient in the face of failure. The resilience allows them to manage failure and learn from their mistakes, rather than become demoralized.

Vicarious experiences is observing a peer succeed at a task strengthen beliefs in one's own abilities. Modeling is a form of vicarious experience; an individual modeling behaviour must ensure that the level of performance is reachable by the observer, social persuasion occurs when people could be persuaded to believe that they have the skills and capabilities to succeed. Consider a time when someone said something positive and encouraging that helped you achieve a goal. Getting verbal encouragement from others helps people overcome self-doubt and instead focus on giving their best to the task at hand thereby raising the individual's self-efficacy. Physiological and emotion (affective) states affect self-efficacy. A positive mood can boost one's beliefs in selfefficacy, while anxiety can undermine it. A certain level of emotional stimulation can create an energizing feeling that can contribute to strong performances. Teachers, for instance, can help by reducing stressful situations and lowering anxiety surrounding events like examinations or presentations.

Anxiety which is an emotion that is experienced in anticipation of some usual ill-defined misfortune influences students' performance. It has been observed that students fear practical agriculture activities and such fear is characterized by practical involvement required by the students in agriculture. This anxiety makes students lose interest in practical agriculture. Moreover, the causes of practical agriculture anxiety include past bad experience in practical science classes, exposure to science anxious teachers who are teaching science and lack of role model. Though some degree of anxiety may be helpful in the learning process, a high level of anxiety impedes optimum performance on science learning (Kurbanoglu \& Akim, 2010; Simsek, 2011). Practical agriculture anxiety could be said to be the feeling of anxiety encountered when taking practical course in agriculture. Avoidance of stressful (practical) activities impedes development of coping skills and the resulting lack of competency provides a realistic basis for anxiety. Acquiring behavioural means for controlling potential threats in practical agriculture eliminates anxiety arousal. Behavioural control in practical agriculture not only allows students to manage the aversive aspects of an environment (farm), it also affects how the farm is likely perceived by the students. Practical stressful situations that can be controlled are observed to be less threatening and such cognitive appraisals further reduce expected anxiety arousal (Bandura, 1977).

\section{Purpose and Objectives}

Practical is a very important aspect of agricultural courses in tertiary institutions in Nigeria. For this reason, all agricultural courses have one aspect or the other. It is in view of the relevance and the importance of practical agriculture in studying agriculture as a future career that this study has been carried out to investigate the perception of students' self-efficacy as a mechanism in sustaining self interest in practical agriculture. Based on the foregoing the purpose of the study was to investigate the students' perception of their self-efficacy as a tool to sustain their interest in agricultural practical. The objectives of the study were to:

i. describe students' interest in practical agriculture; 
ii. describe students' anxiety in practical agriculture;

iii. describe students' self-efficacy in practical agriculture;

iv. describe the relationship between students' self-efficacy and their attitude (interest and anxiety).

\section{Research Questions}

To guide this study, the following research questions were passed:

i. What is the students' interest in practical agriculture?

ii. What is the students' anxiety in practical agriculture?

iii. What is the students' self-efficacy in practical agriculture?

iv. What is the relationship between students' self-efficacy and their attitude (interest and anxiety)?

\section{Hypothesis}

$\mathrm{H}_{01}$ : There is no significant relationship between students' self-efficacy and their attitude (interest and anxiety) to agricultural practical.

\section{Methodology}

\subsection{Population and Sample of the study}

The population (1100) for this study consists of all students in NCE two and three hundred level in the department of agricultural education in College of Education and all the ND II students in the College of Agriculture, both in Taraba state. The choice of these categories of students is on the basis that they must have done practical in agriculture in their previous levels of study.

The population (1100) of the study area was stratified based on the departments in the two tertiary institutions in Taraba state. The strata are the six departments in College of Agriculture and one department in the College of Education. The sample size consisted of 186 agricultural students drawn from the two tertiary institutions in Taraba state for the study. The sample for the study was drawn using proportionate stratified random sampling technique. This technique divides the population into strata (departments) in which samples were selected randomly but independently from each stratum and an estimate of each parameter was computed over all strata (Yalams \& Ndomi, 2000; Jen. 2002; Emaikwu, 2011). Using the sample size table presented by Emaikwu (2011), agricultural students' population of 1100 gave a sample size of 186 . The samples from the two Colleges were drawn by proportionate stratified random sampling technique on the ratio of 3:1 from College of Agriculture (876) and College of Education (224) respectively.

\subsection{Instrumentation}

The study was a descriptive survey design. The study was grounded in the need to describe and interpret the students' self-efficacy in sustaining their interest in agricultural practical in Colleges of Agriculture and Education in Taraba state. A survey design was chosen because descriptive data can be utilized to produce information about various aspects of education (Yalams \& Ndomi, 2000, Gall, Gall, \& Borg, 2003; Emaikwu, 2011). This will in turn lead to empirically based decision making to improve education.

The instrument used to elicit data from sampled respondents was a questionnaire tagged "students' interest and self-efficacy questionnaire" (SISEQ). The instrument was developed by the authors based on relevant literature reviewed in the course of this study. The instrument was a structured questionnaire based on a 5-point rating scale. The instrument was validated by experts 
in agricultural education for both face and content validity (Yalams \& Ndomi, 2000 \& Emaikwu, 2011). A reliability coefficient, Cronbach alpha, of 0.91 was obtained using statistical packaging for social sciences (SPSS) version 16.0. The alpha value was high enough indicating that the instrument was reliable for the study.

\section{Results and Discussion}

The data obtained from the instrument were analyzed using SPSS version 16.0. Descriptive statistics of mean and standard deviation were obtained. A cut-off point of 3.00 and above of mean responses were considered agree or confident while mean responses of below 3.00 were considered disagree or not confident.

A total of 186 agricultural students responded to the questionnaire (SISEQ). About $74.2 \%$ of the respondents were males and $25.8 \%$ were females. The percentage respondents for College of Education were $26.9 \%$ while that of College of Agriculture was $73.1 \%$. These two colleges are the tertiary institutions that offer agricultural courses in Taraba state.

Table 1: Students' mean responses on their interest in practical agriculture

\begin{tabular}{|c|c|c|c|c|}
\hline $\mathrm{S} / \mathrm{N}$ & Statement of interest & Mean & S. d & Remark \\
\hline & Practical agriculture lesson has influenced my interest. & 4.56 & 0.63 & Agree \\
\hline & Practical agriculture books are easy to read. & 4.43 & 0.66 & Agree \\
\hline & I am happy attending practical agriculture class. & 4.34 & 0.72 & Agree \\
\hline & Practical agriculture lessons are not generally boring. & 3.82 & 1.14 & Agree \\
\hline & I would like to learn more about practical agriculture. & 4.41 & 0.89 & Agree \\
\hline & I do not hate practical agriculture lessons. & 4.12 & 1.03 & Agree \\
\hline & I never regret the time I spend in practical agriculture lessons. & 4.25 & 0.85 & Agree \\
\hline 8. & I do not feel afraid when practical agriculture is mentioned. & 4.28 & 0.94 & Agree \\
\hline 9. & I enjoy doing experiments in agriculture laboratory. & 4.23 & 0.93 & Agree \\
\hline & I prefer doing practical agriculture to other things in agriculture laboratory. & 3.90 & 1.08 & Agree \\
\hline 11. & I enjoy talking to other people about practical agriculture. & 4.28 & 0.87 & Agree \\
\hline 12. & I often read ahead in practical agriculture. & 3.96 & 1.08 & Agree \\
\hline
\end{tabular}

Table 1 shows the interest of agriculture students on practical in agricultural courses as required by the first objective. Results indicated that student were interested in practical in agricultural courses taught in their institutions. All the twelve items responded to by the respondents were rated agree with mean rating ranging from 3.82 to 4.56 above 3.00. This agrees with the findings of Ehiemere, Tsojon and Gidado (2011) who established in their study that agriculture students like practical agriculture and lessons in practical agriculture. They added that this has developed in them strong evaluative beliefs about agriculture and also develop strong behavioural tendency to learn practical agriculture.

Table 2: Students' mean responses on their anxiety to agricultural practical

\begin{tabular}{clcc}
\hline S/N & Statement of anxiety & Mean S. d. & Remark \\
\hline 1. I find it difficult to understand practical agric & 2.04 & 1.16 Disagree \\
2. I do not do very well in practical agric & 2.31 & 1.15 Disagree \\
3. I do not remember most of the things I learn in practical agric & 4.19 & 0.88 Agree \\
4. It makes me nervous to think about practical agric & 3.56 & 1.24 Agree \\
5. Class activities in practical agric. upset me & 3.23 & 1.26 Agree \\
6. I often think I cannot do it when a practical agric assignment & 2.71 & 1.28 Disagree \\
7. It scares me to attend agric practical class & 2.73 & 1.35 Disagree
\end{tabular}


8. If I do not see how to do a practical agric assignment right away, 3.051 .29 Agree
I never get it.

The second objective was to determine the anxiety of the respondents to agricultural practical. Table 2 shows the anxiety of the respondents to agricultural practical. The results revealed that four of the eight anxiety items were responded to as agree with mean rating ranging from 3.05 to 4.19 above 3.00 while the remaining four items were rated disagree with mean rating between 2.04 to 2.73 below 3.00 cut off point. These results revealed that students experienced some level of anxiety when taking agricultural practical. The degree of anxiety to some extent challenges (helpful) the learner in the learning process, but a high level of anxiety impedes optimum student's academic performance (Kurbanoglu \& Akim, 2010, \& Simsek, 2011). The degree of anxiety required by the respondents may be responsible for the 50-50 percent responses to the eight items presented in table 2 .

Table 3: Students mean responses on their self-efficacy to practical agriculture

\begin{tabular}{|c|c|c|}
\hline $\mathrm{S} / \mathrm{N}$ & How confident are you: & Mean S.d. Remark \\
\hline 1. & $\begin{array}{l}\text { That after reading an article about practical agric experiment; you } \\
\text { could write a summary of its main point? }\end{array}$ & 4.200 .83 Confident \\
\hline 2. & $\begin{array}{l}\text { That you could explain something you learn in practical agric to } \\
\text { another person? }\end{array}$ & 4.160 .89 Confident \\
\hline 3. & $\begin{array}{l}\text { That after being given homework, you will find materials to answer } \\
\text { the questions? }\end{array}$ & 4.110 .96 Confident \\
\hline 4. & $\begin{array}{l}\text { That after being given a specimen in practical agric you will identify } \\
\text { it? }\end{array}$ & 4.36 0.92 Confident \\
\hline 5. & $\begin{array}{l}\text { That after reading a procedure in practical agric experiment you will } \\
\text { explain the main ideas to another person? }\end{array}$ & 4.200 .88 Confident \\
\hline 6. & $\begin{array}{l}\text { That after watching a television documentary dealing with some } \\
\text { aspects of practical agric you could writes a summary of it main } \\
\text { points? }\end{array}$ & 3.880 .96 \\
\hline 7. & That you could teach another student practical agric? & 4.380 .79 \\
\hline 8. & $\begin{array}{l}\text { That you could ask a meaningful question that could be answered } \\
\text { experimentally? }\end{array}$ & 4.001 .01 Confident \\
\hline 9. & will be successful (pass) in practical agric courses? & 4.270 .88 \\
\hline 10. & erstand the subject ar & 3.931 .05 Confident \\
\hline 11. & $\begin{array}{l}\text { In your ability to understand and use mathematics to solve practical } \\
\text { agric problem? }\end{array}$ & 3.59 1.16 Confident \\
\hline 12. & o organize your time and use it effectively? & 3.791. \\
\hline 13. & $\ln y$ & 4.121 .00 \\
\hline 14 & $\begin{array}{l}\text { In your ability to find time to complete your assignment in practical } \\
\text { agric? }\end{array}$ & 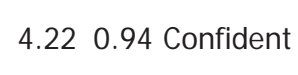 \\
\hline 15. & In your ability to use appropriate skills to report on practical agric? & 4.05 0.91 Confident \\
\hline 16 & $\begin{array}{l}\text { In your ability to obtain resources, e.g. practical books from the } \\
\text { library? }\end{array}$ & 3.921 \\
\hline 17. & enjoy writing examination in & 4.210 .92 Confident \\
\hline 18 & & 4.04 1.05 Confident \\
\hline 19. & $\begin{array}{l}\text { In your ability to understand the subject matter of practical agric } \\
\text { course? }\end{array}$ & 4.19 0.95 Confident \\
\hline
\end{tabular}

The third objective was to determine the students' self-efficacy to practical in agricultural activities in their institutions of learning. Table 3 shows the self-efficacy of the respondents. The result revealed that all the nineteen items on students' self-efficacy were rated confident with mean 
rating ranging from 3.59 to 4.38 above the cut-off point of 3.00 . The result revealed that the respondents were efficacious to practical in agricultural courses which is likely attributed to the sources of self-efficacy. Self-efficacy is shaped by how students perform course assignments and pre-career experiences, by observing their peers and instructors perform expected tasks, from mentoring and positive feedback, and how they handle their anxieties in challenging situations (Zarafshani, Knobloch \& Aghahi, 2008).

Hypothesis $\left(\mathrm{H}_{01}\right)$ : There is no significant relationship between students' self-efficacy and their attitude (interest and anxiety) towards practical agriculture.

Table 4: Relationship between students' self-efficacy and their attitude to practical agriculture

\begin{tabular}{cccccc} 
& Attitude & $\mathrm{N}$ & Mean & s. d. & $\mathrm{r}$ \\
\cline { 2 - 6 } & Interest & 186 & 4.22 & 0.45 & $0.450^{* *}$ \\
Anxiety & 186 & 2.98 & 0.70 & 0.009 \\
\hline
\end{tabular}

$P<0.01$

The hypothesis was tested using Pearson correlation statistics. In the correlation, the students' selfefficacy responses were pooled together and correlated with their pooled responses on interest and anxiety. Table 4 revealed that students' self-efficacy has a positive and significance relationship ( $r$ $=0.460 * *)$ with their interest towards practical agriculture while the relationship $(r=-0.009)$ with anxiety is minimally negative and not significant. This means that students who are efficacious have interest in practical agriculture. The implication is that students' interest in practical agriculture can be sustained by their self-efficacy. This finding is in consonant with Bandura, 1986 \& 1997; Niemivirta \& Tapola, 2007; du Preez, 2010; Bandura, Barbaranelli, Caprara \& Pastorelli, 2001 \& Ajegbomogun, 2011 who maintained that self-efficacy plays a role in a students' academic motivation in terms of choice of activity, amount of effort on the academic task and the persistence shown in completing academic task.

\section{Conclusion and Recommendations}

The findings and discussion of the study indicated that the respondents (students) in the study area (Colleges of Agriculture and Education both in Jalingo, Taraba state, Nigeria) indicated strong positive interest to agricultural practical. The interest of the respondents must have been motivated by their agricultural teachers (lecturers), peers, careers in agriculture and environment (Ehiemere, Tsojon \& Gidado, 2011). The level of anxiety indicated by the respondents revealed that it was minimal which was within the acceptable range which is said to be helpful to learning (Kurbanoglu $\&$ Akim, $2010 \&$ Simsek, 2011). Agricultural students in the study area are efficacious (confident) in general terms such as performing difficult tasks, confronting obstacles and coping in the face of adverse situations.

Based on the findings of the study, the following recommendations are presented;

i. Teachers of agriculture should continue to raise the interest of students on practical agriculture through various pedagogical methods to enable the students learn and excel in agriculture to bring about the desired national development.

ii. Seminars, workshops, training and re-training should be organized on regular basis for teachers (lecturers) of agriculture on how to minimize and manage anxiety in practical agriculture for effective learning by the students.

iii. Curriculum developers should consider self-efficacy when developing essential employability skills as this can help students adapt and succeed in many different situations.

iv. Agricultural teachers should develop students' awareness of their self-efficacy through modeling to enable them exclaim, "I can do it". 
v. General self-efficacy should be considered when preparing students for national and international experiences in science and in agriculture particularly.

vi. Students should be encouraged to be having group study.

vii. Students should be motivated to develop appropriate skills in writing reports in practical agriculture.

\section{References}

Ajegbomogun, F.O. (2011). self-efficacy. Availability, accessibility and utilization of internet information resources as determinants of research productivity of lecturers in Nigerian Agricultural Universities. Ph.D seminar. University of Ibadan.

Bandura, A. (1977). Self-efficacy: Toward a Unifying theory of behavioural change. Psychological review. 84(2): 191-215

Bandura, A. (1982). Self-efficacy mechanism in human agency. American Psychologist. 37(2): 122-147.

Bandura, A. (1986). Social foundations of thought and action: A social cognitive theory. England Cliffs, NJ : Prentice-Hall

Bandura, A. (1994). Self-efficacy. In V.S. Ramachaudran (Ed). Encyclopedia of human behaviour, 4. New York: Academic Press, PP. 71-81.

Bandura, A. (1997). Self-efficacy: the exercise of control. New York: W.H. Freeman and Company.

Bandura, A.; Barbaranelli, C.; Caprara, G.V. and Pastorelli, C. (2001). Self-efficacy beliefs as shapers of children's aspirations and career trajectories. Child development. 72(1): 187-206.

Carmichael, C. and Watson, J. (2010). Statistical literacy in the middle school: the relationship between interest, self-efficacy and prior mathematics achievement. Australian journal of educational \& developmental psychology. 10; 83-93.

du Preez, J. (2010).co-constructing self-efficacy narratives. A study of four mature age university students. Unpublished Ph.D Dissertation. Queensland University of Technology.

Edziwa, X. and Chivheya, R. (2012). Agricultural teacher education in Zimbabwe: A teacher-mentors view of trainee teachers holding National Certificate in Agriculture. Journal of engineering trends in educational research and policy studies (JETERAPS). 3(4):495-500.

Ehiemere, G.A.; Tsojon, J.D. and Gidado, I. (2011). Altitude of agricultural education students towards practical agriculture in college of education, Jalingo Taraba state. Journal of Education as Innovators. 4(1): 189-194.

Emaikwu, S.O. (2011). Fundamentals of research methods and statistics. Makurdi: Selfers Academic press limited

Gall, M. Gall. J. and Borg, W. (2003). Education research: An introduction. Boston: Longman.

Hartfield, K.N. (2011). Perceived levels of teacher self-efficacy among secondary Arizona agricultural education teachers. Unpublished M.Sc thesis. The University of Arizona.

Hashemi, S.M.K., Hosseinin, S.M. and Rezvantar (2012). Explaining entrepreneurial intention among agricultural students: Effects of entrepreneurial self-efficacy and college entrepreneurial orientation. Research journal of business management. 1-9. ISSN 1819-1932/DOI:10.3923/rjbm.2012.

J en, S.U. (2002). Fundamentals of research Methodology. Yola: Paraclete Publishers.

Kurbanoglu, N.I. and Akim, A. (2010). The relationships between university students' chemistry laboratory anxiety, attitudes and self-efficacy beliefs. Australian Journal of teacher Education. 38(8): 47-58.

Niemivirta, M. and Tapola, A. (2007). Self-efficacy interest and task performance: within task changes, mutual relationships and predictive effects. Zeitschrift fiir padagogische psychologie. 21(3/4): 241250.

Pintrich, P.R. and Schunk, D.H. (2002). Motivation in education: theory, research and applications (2nd Ed). Upper Saddle, NJ : Prentice-Hall, Inc.

Roberts, T.G. and Dyer, J.E. (2005). The relationship of self-efficacy, motivation and critical thinking disposition to achievement and attitudes when an illustrated web lecture is used in an online learning environment. J ournal of Agricultural Education. 46(2): 12-23. 
Simsek, A. (2011). The relationship between computer anxiety and computer self-efficacy. Contemporary educational technology. 2(3): 177-187.

Tenaw, Y.A. (2013). Relationship between self-efficacy, academic achievement and gender in analytical chemistry of Debre Markos College of Teacher Education. AJ CE. 3(1): 3-28.

Wolf, K.J. (2008). Agricultural education teachers' self-efficacy. A descriptive study of beginning agricultural education teachers in Ohio. Unpublished Ph.D Dissertation. The Ohio state university.

Yalams, S.M. and Ndomi, B.M. (2000). Research Project writing and Supervision. Bauchi: League of researchers in Nigeria.

Zarafshami, K., Knobloch, N.A., and Aghahi, H. (2008). General perceived self-efficacy of I ranian College of Agriculture Students. J ournal of International Agricultural and extension education. 15(1): 69-84.

Zimmerman, B.J . and Cleary, T.J. (2006). Adolescents' development of personal agency. The role of selfefficacy beliefs and self-regulatory skills. Self-efficacy beliefs of adolescents. 45-69. 
